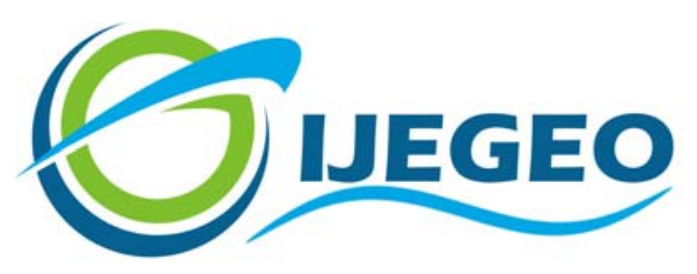

International Journal of Environment and Geoinformatics (IJEGEO) is an international, multidisciplinary, peer reviewed and certified open access journal.

\title{
Seasonal variations in physico-chemical parameters of Buleji and Paradise Point rocky shores at Karachi coast
}

\section{Fatima Hayat Shaheen Zafar, Zarrien Ayub, Aasia Karim, Mohammad Zahid and Levent Bat}

\author{
Editors \\ Prof. Dr. Cem Gazioğlu, Prof. Dr. Dursun Zafer Şeker, Prof. Dr. Ayşegül Tanık, \\ Prof. Dr. Şinasi Kaya, Assist. Prof. Dr. Volkan Demir
}

\section{Scientific Committee (2018)}

Dr. Abdullah Aksu, Prof. Dr. Bedri Alpar, Prof. Dr. Gülşen Altuğ, Prof. Dr. Lale Balas, Prof. Dr. Can Balas, Prof. Dr. Levent Bat, Prof. Dr. Bülent Bayram, Prof. Dr. Nuray Çağlar, Prof. Dr. Jadunandan Dash, Prof. Dr. A. Evren Erginal, Dr. Dieter Fritsch, Dr. Amin Gharehbaghi, Assoc. Prof. Dr. Tolga Görüm, Prof. Dr. Melike Gürel, Dr. Hakan Kaya , Prof. Dr. Fatmagül Kılıı̧, Assoc. Prof. Dr. Maged Marghany, Prof. Dr. Nebiye Musaoğlu, Prof. Dr. Masafumi Nakagawa, Prof. Dr. Haluk Özener, Prof. Dr. Erol Sarı, Prof. Dr. Elif Sertel, Prof. Dr. Nüket Sivri, Assoc. Prof. Dr. Füsun Balık Şanlı, Prof. Dr. Uğur Şanlı, Assoc. Prof. Dr. Hasan Özdemir, Prof. Dr. Taşkın Kavzoğlu, Msc. Mustafa Üstüner, Assoc. Prof. Dr. Oral Yağcı, Prof. Dr. Seyfettin Taş, Assoc. Prof. Dr. Ömer Suat Taşkın, Assoc. Prof. Dr. İ. Noyan Yılmaz, Dr. Baki Yokeş, Dr. Sibel Zeki 


\title{
Seasonal variations in physico-chemical parameters of Buleji and Paradise Point rocky shores at Karachi coast
}

\author{
Fatima Hayat Shaheen Zafar*1 ${ }^{1}$ Zarrien Ayub ${ }^{2}$, Aasia Karim ${ }^{1}$, Mohammad Zahid ${ }^{1}$, \\ Levent Bat $^{3}$
}

${ }^{1}$ Department of Zoology, Federal Urdu University of Arts, Science and Technology, Karachi-75270, Pakistan
${ }^{2}$ Centre of Excellence in Marine Biology, University of Karachi, Karachi-75270, Pakistan
${ }^{3}$ Sinop University Fisheries Faculty, Department of Hydrobiology, TR57000 Sinop, Turkey

\author{
Corresponding author* \\ Tel :009203343353508 \\ E-mail : fatimahamood@yahoo.com
}

\begin{abstract}
The aim of the current study was to determine common physico-chemical parameters (salinity, temperature, chlorophyll- $a$, dissolved oxygen, and $\mathrm{pH}$ ) of coastal water of two rocky shores from Buleiji and Paradise Point rocky shores at Karachi monthly basis, from November 2007 to April 2009. The range of air and surface water temperature of Buleji varies from $19{ }^{\circ} \mathrm{C}$ to $30{ }^{\circ} \mathrm{C}$ and $21^{\circ} \mathrm{C}$ to $29{ }^{\circ} \mathrm{C}$, respectively. Almost similar air temperature and seawater temperature $\left(19^{\circ}\right.$ to $\left.29^{\circ} \mathrm{C}\right)$ were recorded at Paradise Point. Salinity ranged from 35 to $39 \%$ at Buleji while it ranged between 35 to $40 \%$ at Paradise Point. The lowest concentrations of dissolved oxygen was recorded in November'07 and November'08 at both sites, at Buleiji which were $1.6 \mathrm{mg} / \mathrm{L}$ and 1.7 $\mathrm{mg} / \mathrm{L}$ while at Paradise Point it was $1.8 \mathrm{mg} / \mathrm{L}$ and $1.7 \mathrm{mg} / \mathrm{L}$, respectively. The $\mathrm{pH}$ value ranged from 7.0 to 8.3 at Buleji and from 7.5 to 8.4 at Paradise Point. The concentrations of chlorophyll- $a$ were between 1.2 and 3.7 $\mu \mathrm{g} \mathrm{cm}-2$ at Buleji while it ranged from 0.9 to $3.3 \mu \mathrm{g} \mathrm{cm}-2$ at Paradise Point. Results showed that the obtained values of temperatures, salinity, $\mathrm{pH}$ and chlorophyll-a are favorable for the continued survival of marine biota but the values of dissolved oxygen were found to be below $4 \mathrm{mg} / \mathrm{L}$ which are not suitable for various species. Prolonged periods of minimal dissolved oxygen directly upset larval stages of numerous marine organisms. In Karachi coastal areas, seasonal accessibility of surface water is very responsive to the monsoon climate and physiography of coastal belt. These concerns were used to inform the common people and decision-makers about the state of the coastal environments. To protect these dynamic significant habitats, the government organizations and researchers should work with appropriate consideration.
\end{abstract}

Keywords: Physico-chemical parameters, Chlorophyll- $a$, rocky shore, Karachi coast, the Northeastern Arabian Sea

\section{Introduction}

Hydro biological studies are the important one associated with flora and fauna of the marine and estuarine environment. Maintenance of good water quality is essential for the survival of the aquatic habitats. (Thakur Bignesh et al. 2014). The environs contain specialized habitats like salt marshes, coral reefs and mangroves and each habitat has their specific animal community (Trivedi et al. 2012). Physicochemical properties of the marine environment will play a dynamic role in determining the type of ecosystems (Thakur Bignesh et al. 2014).Changes in the physico- chemical parameters provide valuable information on the quality of water (Bat and Gökkurt-Baki 2014), the sources of their differences and their effects on the functions and biodiversity of the water body (Elahi et al. 2015). Physico-chemical and micro-biological characteristics may describe the quality of water (Priyanka et al. 2009). Better quality of water can be described by its physical, chemical and biological characteristics. But, some correlation was possible among these parameters and the significant one would be useful to indicate the quality of water (Manjare et al. 2010). Estuarine and coastal areas are complex and dynamic aquatic environment 
(Anitha G and Sugirtha P. K 2013). Moreover, when river water combines with marine water, a lot of physical and chemical procedures occur, this may effect on water quality (Muduli B.P and Panda C.R 2010). Yet little information exists on temporal and spatial variation in nearshore environment. To establish the spatial and temporal variations in water quality, regular monitoring programs are required.

The region of Arabian Sea adjoining the coast of Pakistanis considered as one of the dynamic areas in the world and is rich in fish and shellfish fauna. About 1100 species of molluscs are known to occur in the northern Arabian Sea, comprising of gastropods, bivalves, cephalopods and others. Among these 30 species could be regarded as economically important on the coast of Pakistan (Moazzam and Ahmed 1994). The $1050 \mathrm{~km}$ coastline of Pakistan which is divisible into Sindh and Balochistan coasts is mostly bare desert with unique land forms, such as sandy beaches, mud flats, rocky cliffs, head lands, bays, deltas, etc. The inner shelf hydrography of two sites at Karachi i.e. Buleiji and Paradise Point dominated as rocky beach with slightly different coastline location. The Sindh and Balochistan coast experiences almost the same range of temperature and rainfall, having long warm summer $\left(21^{\circ}\right.$ to $\left.39^{\circ} \mathrm{C}\right)$ and short mild winter $\left(10^{\circ}\right.$ to $\left.20^{\circ} \mathrm{C}\right)$ and rainfall is low, $<250$ mm annually.

Temperature is a monitoring effect in the marine environment. (Odum 1971; Boyd. 1979). It influences metabolic activities, development, nourishing, reproduction, distribution and migratory activities of aquatic organisms. (Largler et al. 1977; Suski et al . 2006).

$\mathrm{pH}$ as one of the dynamic environmental features decides the survival, metabolism, physiology and growth of aquatic organisms. $\mathrm{pH}$ is influenced by acidity of the bottom sediment and biological activities. (Lawson, E.O. 2011).

Salinity is a fundamental water quality parameter monitored by freshwater and marine ecologists because of its influence on the biota. (Sreenivasulu et al. 2015). Salinity determines distribution of organisms in aquatic environments. (Lawson, E.O. 2011). Boyd and Lichtkoppler (1979) reported $\mathrm{pH}$ range of 6.09 -
8.45 as being ideal for supporting aquatic life including fish.

Dissolved oxygen (DO) affects the solubility of and availability of nutrients. Its low levels can result in damages to oxidation state of substances from the oxidized form to the reduced form, thereby increasing the levels of toxic metabolites. Dissolved Carbon dioxide in aquatic environment is increased with decreases of DO (Elahi et al. 2015). Although according to Lawson, E.O (2011) Oxygen solubility decreases slightly as salinity increases.

Phytoplankton as chlorophyll-containing organisms is the first step of production in most marine processes and food chains. Chlorophyll concentration is one of the key indices in the study of the health status of any natural marine ecosystem. Very low and high levels of concentrations of chlorophyll- $a$ can be harmful to marine biota. Chlorophyll-a concentrations can act as an indicator of phytoplankton abundance and biomass in the coastal waters. Therefore, the investigation on variations of chlorophyll- $a$ is very important to the study of water quality and marine pollution in the Sea. It is natural for levels of chlorophyll- $a$ to fluctuate over the different seasons (Jamshidi, S and Bin Abu Bakar, N 2011). Physico-chemical parameters affected the primary production in different seasons; the primary production varied from season to season with the load of nutrient salts in addition to phytoplankton species (Muduli and Prasanna 2010).

The present research comprises to measure seasonally variation in physico-chemical parameters such as surface water temperature $\left({ }^{\circ} \mathrm{C}\right)$, air temperature $\left({ }^{\circ} \mathrm{C}\right)$, DO $(\mathrm{mg} / \mathrm{L})$, salinity (\%o), $\mathrm{pH}$ and chlorophyll- $a$ from two protected and non-protected rocky shores of Karachi coast.

\section{Materials and Methods}

\section{Study Area \\ Karachi Coast}

The coast of Karachi (Figure 1.) located on the northeastern border of the Arabian Sea is about $90 \mathrm{~km}$ long (Rizvi et al., 1995). Its geographic coordinates are $24^{\circ} 48^{\prime} \mathrm{N}$ latitude and $66^{\circ} 59^{\prime}$ E longitude. On the western side, Karachi coast is restricted by the Hub River and on its east are located the mangrove swamps and creeks of the 
Port Qasim area. The Lyari and Malir rivers are the seasonal streams which flow during SW monsoon (summer). At Karachi the mean annual total rainfall usually vary between 125 $250 \mathrm{~mm}$ with average day relative humidity of 70 percent taken from Pakistan Meteorological Department. Two rocky ledges, Buleji and Paradise were selected for study, which lie adjacent to each other on Karachi coast.

\section{Buleji}

Buleji rocky ledge lies at $24^{\circ} 49^{\prime} \mathrm{N}$ and $66^{\circ} 50^{\prime}$ E of Karachi between Hawks Bay and Paradise Point (Figure 1), covering an area of about 800 meters. The ledge is triangular in shape and divisible into an exposed area which faces the open ocean and is under high wave action. The western protected side of the ledge is exposed to less wave action and is totally submerged on high tides. The intertidal zone of the exposed ledge consists of slightly elevated and depressed areas here and there (see appendix Plate 1). Boulders of various sizes are scattered mostly in the high tidal zone. The mid and low tidal zones are made up of rather flat rocks and comparatively smaller boulders. Different sizes of rock pools are present in mid and low tidal zones. The high tidal zone is mostly occupied by gastropods and barnacles. The mid and low tidal zones are occupied by gastropods, crustaceans (crabs, pistol shrimps and amphipod), echinoderms (sea-cucumber and sea-urchin), bivalves (mussels and oysters), etc. The ledge is rich in algal vegetation. Buleji rocky ledge is a restricted area with no access to general public as is the other study site, Paradise Point.

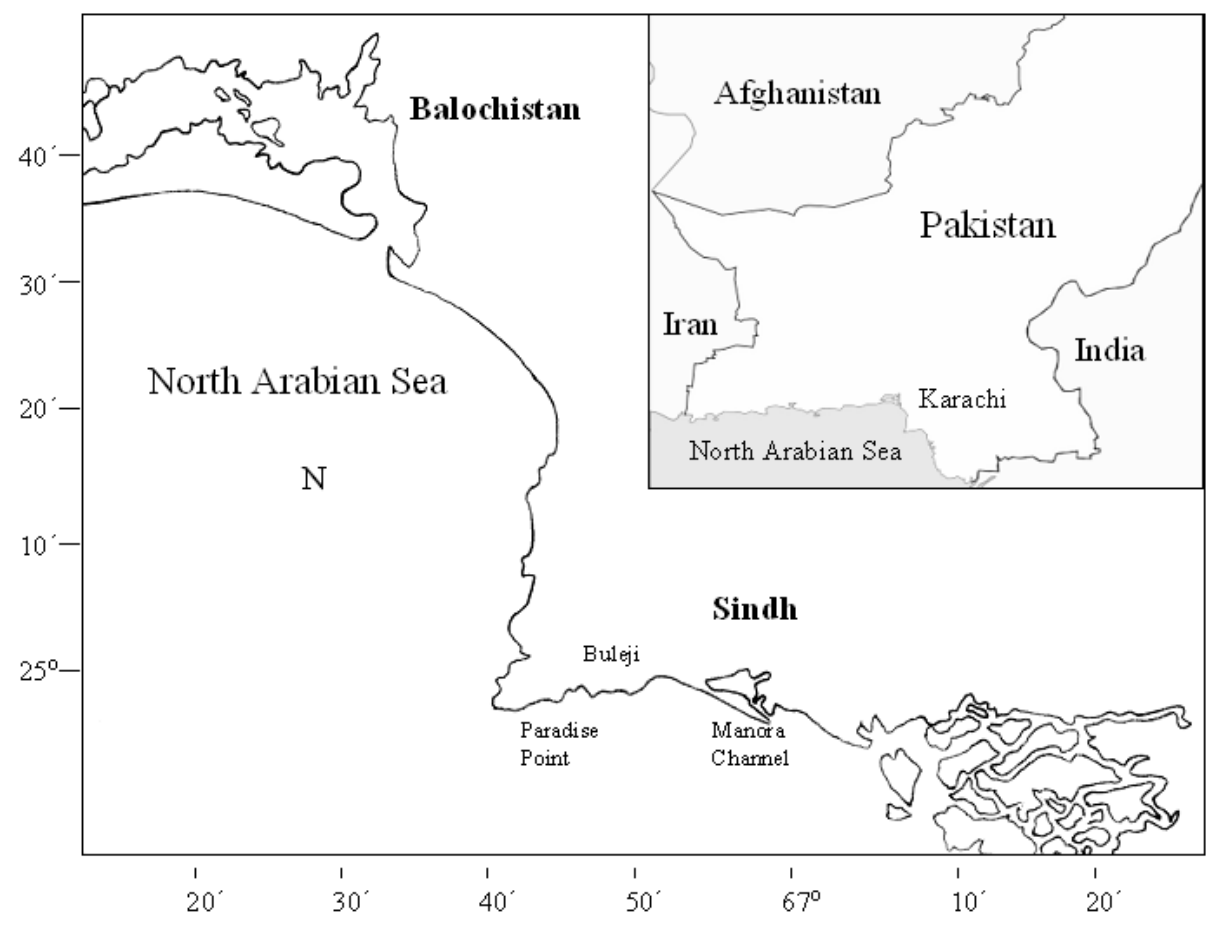

Fig 1. Map showing the collection sites, Buleji and Paradise Point on the coast of Karachi. Inset: showing the coastline of Pakistan.

\section{Paradise Point}

The Paradise Point (Figure 1.) is situated at $24^{\circ}$ $50^{\prime} \mathrm{N}$ and $66^{\circ} 48^{\prime} \mathrm{E}$ of Karachi between Buleji and Nathiagali. The slope of the shoreline of Paradise Point shows a sharp slope towards the sea which results in narrow intertidal zone. The bottom of the shore is enclosed by boulders which are rather flat as compared to Buleji which showed elevations and depressions (see appendix Plate 2). On western side of this site 
have Rocky Mountains about 30 meters in height. In the supratidal zone a rocky mountain, 10 meters in height and 10 meters in length covered abundantly with limpets and barnacles can be seen (Plate 2). The other fauna in this area is scanty probably due to the location of Karachi Nuclear Power Plant which is operational since 1972. Paradise Point is also used by general public for entertaining purposes.

\section{Tidal zone}

Tides along the coast of Pakistan are semidiurnal, which produces unequal tides. The tidal range varies from $1.8 \mathrm{~m}$ to $3.2 \mathrm{~m}$ on the coast of Pakistan (Saifullah 1973). The tidal range at Karachi is $2.3 \mathrm{~m}$ (Tariq et al. 2002). Due to the influence of SW monsoon waves, the intertidal area remains uncovered for a shorter duration in summer than in winter. The lowest low tides occur in the afternoon in summer and early morning in winter. On the basis of tidal range each shore was arbitrarily divided into three zones, that is, low, mid and high tidal zones in the present study.

\section{Humidity and Precipitation}

The humidity in Karachi where the two rocky shores are situated varied between 57 to $82 \%$, being relatively lower in winter than summer. The rainfall during most of the study period was either absent or almost negligible $(<0.5$ $\mathrm{mm}$ ), being highest in July and August (SW monsoon) (Figure 2.4.).

\section{Physico-chemical parameters}

Water samples were collected every month from November 2007 to April 2009. Samples for each site collected in the intertidal area during the high tide time. The care was taken of the collected samples during the carrying to the laboratory for the further parameter analysis. Physicochemical properties of water were verified according to the standards of the American Public Health Association (APHA 2005). The common Physico-chemical parameters of water (temperature, $\mathrm{pH}$, salinity, total DO and chlorophyll- $a$ ) have been determined. To compare the data for seasonal variations, the months between November to
February and between May to September are referred as northeast monsoon (winter) and southwest monsoon (summer), respectively. The months between March to April and October are the transition periods between two seasons, referred as spring inter-monsoon and autumn inter-monsoon, respectively.

\section{Air temperature}

Temperatures were measured directly by with mercury-in-glass thermometer. For the samples of air temperature, the thermometer was held up right in the air with the fingers and with the lower part exposed to the air for about 4-5 min. The average values for air and water temperatures were recorded as degrees centigrade $\left({ }^{\circ} \mathrm{C}\right)$.

\section{Water temperature}

The samples of water collected directly from the location. The water temperature were measured at the sampling point with mercuryin-glass thermometer, which was immersed in water $6 \mathrm{~cm}$ below the water surface and left to stabilize for $5 \mathrm{~min}$. Water temperatures were recorded as degree centigrade $\left({ }^{\circ} \mathrm{C}\right)$.

\section{Salinity (\%)}

The salinity was measured in the field by Handheld Refractometer (Atago, S/Mill-E).

\section{$\mathrm{DO}(\mathrm{mg} / \mathrm{L})$}

For measuring dissolve oxygen the water sample was fixed in $300 \mathrm{ml}$ dark glassstoppered bottle and was measured in the laboratory by YSI DO 200/Eco Sense Oxygen Meter.

$p H$

The $\mathrm{pH}$ was determined by THOMAS SCIENTIFIC TS $625 \mathrm{pH}$ Meter in the laboratory.

\section{Chlorophyll-a}

Three rock chips $\left(2 \mathrm{~cm}^{2}\right)$ were randomly collected using chisel and hammer. The chips were transferred to the laboratory in dark box. 
The chlorophyll- $a$ was extracted from each sample using the cold methanol method (HMSO, 1986), where each chip was transferred to $12 \mathrm{ml}$ methanol and were stored at $4^{\circ} \mathrm{C}$ for 24 -hin dark. The extract was filtered and measured using spectrophotometer (MODEL S-20, BOECO, GERMANY) at 665 $\mathrm{nm}$ and $750 \mathrm{~nm}$.

Chlorophyll- $a$ concentration was measured using the equation:

$$
\mathrm{C}=\frac{13.9 \times \mathrm{A} \times \mathrm{V}}{\mathrm{d} \times \mathrm{V}}\left(\boldsymbol{\mu g} \mathrm{cm}^{2}\right)
$$

where $\mathrm{A}=$ Absorbance $665 \mathrm{~nm}-750 \mathrm{~nm}$

$\mathrm{v}=$ volume of solvent in $\mathrm{ml}(12 \mathrm{ml})$

$\mathrm{V}=$ area of rock sampled in $\mathrm{cm}^{2}$

$\mathrm{d}=$ cell path length in $\mathrm{cm}(4 \mathrm{~cm})$

$13.9=$ constant

\section{Results}

The air temperature fluctuated from $19^{\circ}$ to $30^{\circ}$ $\mathrm{C}$ and seawater temperature extended from $21^{\circ}$ to $29^{\circ} \mathrm{C}$ at Buleji (Figure 2). Almost similar air temperature $\left(19^{\circ}\right.$ to $\left.29^{\circ} \mathrm{C}\right)$ and seawater temperature $\left(19^{\circ}\right.$ to $\left.29^{\circ} \mathrm{C}\right)$ variations were recorded at Paradise Point (Figure 2). Throughout the study period air temperature was lowest (average $21.5 \pm 1.90^{\circ} \mathrm{C}$ ) in winter (NE monsoon) and highest in summer or SW monsoon (average $26.4 \pm 2.88^{\circ} \mathrm{C}$ ). The seawater temperature was also lowest in $\mathrm{NE}$ monsoon (average $24.5 \pm 1.29^{\circ}$ C) with impulsive increase in spring inter-monsoon (average $28.0 \pm 0.00^{\circ} \mathrm{C}$ ) and remained high during the summer (average $27.2 \pm 1.30^{\circ} \mathrm{C}$ ) (Table 1). Virtually a similar association of seasonal variation in air and surface water temperatures was observed at Paradise Point (Table 1).

Virtually a similar association of seasonal variation in air and surface water temperatures was observed at Paradise Point (Table 1). The analysis of variance showed no significant difference between seawater temperatures (ANOVA, $\mathrm{F}=0.292 ; \mathrm{P}>0.05$ ) at two sites. There was significant correlation between air and seawater temperatures $(\mathrm{r}=0.832 ; \mathrm{P}=0.01$; $\mathrm{n}=18)$ at Buleji and $(\mathrm{r}=0.880 ; \mathrm{P}=0.01 ; \mathrm{n}=$ 18) at Paradise Point (Table 2).

Salinity ranged from 35 to $39 \%$ at Buleji while it was between 35 and $40 \%$ at Paradise Point (Figure 3 ). Although the salinity did not differ much throughout the year, the lowest salinity was recorded in the SW monsoon, at both sites (Table 2). The lowest concentrations of dissolved oxygen $1.6 \mathrm{mg} \mathrm{L}^{-1}$ and $1.7 \mathrm{mg} \mathrm{L}^{-1}$ was recorded in November'07 and November'08at Buleji, respectively (Figure 3). The analysis of variance showed no significant difference between salinity (ANOVA, $\mathrm{F}=0.093 ; \mathrm{P}>$ $0.05)$ at two sites.

The lowest concentrations of dissolved oxygen were also recorded in the same two months at Paradise Point (Figure 3). There was a seasonal pattern in the concentration of dissolved oxygen at Buleji, being highest $(3.7 \pm 1.36$ and $3.6 \pm$ $\left.1.30 \mathrm{mg} \mathrm{L}^{-1}\right)$ in NE monsoon and lowest $(2.2 \pm$ $0.00 \mathrm{mg} \mathrm{L}^{-1}$ ) in autumn inter-monsoon (Table 1). However, this seasonal pattern of dissolved oxygen concentration was not so evident at Paradise Point (Table 1). According to Soundarapandian et al. (2009) the variation in the DO concentration is due to many factors such as photosynthesis and respiration. While Manasrah et al. (2006) observed in the uppermost waters, where the temperature rises above $25 \mathrm{C}$, oxygen concentrations may decrease as a result of the lower solubility of oxygen in warmer seawater. In the present study during the NE monsoon seasons the lowest sea water temperature $24.5 \pm 1.29$ recorded with high concentration of DO $3.6 \pm$ 1.30 at Buleiji. High temperature causes the oxygen to be relatively low (Badran 2001). The concentration of dissolved oxygen varied from 1.6 to $4.6 \mathrm{mg} \mathrm{L}^{-1}$ at Buleji (Figure 3). The analysis of variance showed no significant difference between concentrations of dissolved oxygen (ANOVA, $\mathrm{F}=0.529 ; \mathrm{P}>0.05$ ) at two sites. There was significant correlation between concentrations of dissolved oxygen and chlorophyll- $a(\mathrm{r}=0.889 ; \mathrm{P}=0.01 ; \mathrm{n}=18)$ at Buleji and $(\mathrm{r}=0.761 ; \mathrm{P}=0.01 ; \mathrm{n}=18)$ at Paradise Point (Table 2). The analysis of variance showed no significant difference between $\mathrm{pH}$ (ANOVA, $\mathrm{F}=0.284 ; \mathrm{P}>0.05$ ) at two sites.

The $\mathrm{pH}$ value ranged from 7.0 to 8.3 at Buleji and from 7.5 to 8.4 at Paradise Point (Figure 3). Though no seasonal pattern was evident in the $\mathrm{pH}$ value at two sites, however, it was comparatively higher in autumn inter-monsoon and NE monsoon (Table 1). 
Table 1. Seasonal variations in the mean values $( \pm$ SD) of the physio-chemical parameters at two rocky ledges during the period from November 2007 to April 2009

\begin{tabular}{|c|c|c|c|c|c|c|c|}
\hline Sites & Seasons & $\begin{array}{l}\text { Temperature } \\
\text { of air }\left({ }^{\circ} \mathrm{C}\right)\end{array}$ & $\begin{array}{l}\text { Temperature } \\
\text { of sea }\left({ }^{\circ} \mathrm{C}\right)\end{array}$ & $\begin{array}{l}\text { Salinity } \\
\text { (ppt) }\end{array}$ & $\begin{array}{l}\text { Dissolve Oxygen } \\
\left(\mathrm{mg} \mathrm{L}^{-1}\right)\end{array}$ & $\mathrm{pH}$ & $\begin{array}{l}\text { Chlorophyll-a } \\
\left(\mu \mathrm{g} \mathrm{cm}^{-2}\right)\end{array}$ \\
\hline \multirow[t]{6}{*}{ Buleji } & Northeast monsoon & $21.5 \pm 1.90$ & $24.5 \pm 1.29$ & $38.0 \pm 1.41$ & $3.6 \pm 1.30$ & $7.9 \pm 0.28$ & $3.1 \pm 0.95$ \\
\hline & Spring Inter-monsoon & $25.5 \pm 0.71$ & $28.0 \pm 0.00$ & $37.0 \pm 2.83$ & $3.2 \pm 1.48$ & $7.8 \pm 0.67$ & $3.3 \pm 0.49$ \\
\hline & Southwest monsoon & $26.4 \pm 2.88$ & $27.2 \pm 1.30$ & $36.8 \pm 1.64$ & $2.7 \pm 0.88$ & $7.6 \pm 0.57$ & $1.6 \pm 0.82$ \\
\hline & Autumn Inter-monsoon & $25.0 \pm 0.00$ & $26.0 \pm 0.00$ & $38.0 \pm 0.00$ & $2.2 \pm 0.00$ & $8.1 \pm 0.00$ & $2.5 \pm 0.00$ \\
\hline & Northeast monsoon & $21.8 \pm 1.26$ & $23.2 \pm 2.22$ & $39.0 \pm 0.00$ & $3.7 \pm 1.36$ & $8.1 \pm 0.17$ & $2.8 \pm 1.09$ \\
\hline & Spring Inter-monsoon & $25.5 \pm 2.12$ & $28.0 \pm 1.41$ & $37.0 \pm 2.83$ & $3.3 \pm 1.41$ & $7.9 \pm 0.53$ & $3.0 \pm 0.71$ \\
\hline \multirow[t]{6}{*}{ Paradise Point } & Northeast monsoon & $21.5 \pm 2.38$ & $23.8 \pm 1.50$ & $38.0 \pm 1.41$ & $3.0 \pm 0.99$ & $7.9 \pm 0.43$ & $2.4 \pm 0.85$ \\
\hline & Spring Inter-monsoon & $26.5 \pm 0.71$ & $28.0 \pm 1.41$ & $36.5 \pm 2.12$ & $2.8 \pm 0.57$ & $7.8 \pm 0.39$ & $2.7 \pm 0.21$ \\
\hline & Southwest monsoon & $26.0 \pm 2.00$ & $27.4 \pm 1.52$ & $36.4 \pm 1.14$ & $3.2 \pm 0.26$ & $7.9 \pm 0.32$ & $2.3 \pm 0.15$ \\
\hline & Autumn Inter-monsoon & $25.0 \pm 0.00$ & $27.0 \pm 0.00$ & $40.0 \pm 0.00$ & $3.3 \pm 0.00$ & $8.2 \pm 0.00$ & $2.4 \pm 0.00$ \\
\hline & Northeast monsoon & $21.3 \pm 1.50$ & $22.5 \pm 1.73$ & $38.8 \pm 0.50$ & $3.2 \pm 1.23$ & $8.1 \pm 0.21$ & $2.5 \pm 1.11$ \\
\hline & Spring Inter-monsoon & $25.5 \pm 0.71$ & $26.0 \pm 2.83$ & $36.5 \pm 2.12$ & $2.7 \pm 0.64$ & $7.8 \pm 0.38$ & $2.5 \pm 0.35$ \\
\hline
\end{tabular}

Table 2. Pearson's correlation between physico-chemical parameters at Buleji and Paradise Point (*Correlation is significant at the 0.01 level). 
Zafar et al. / IJEGEO 5 (2) 154-168 (2018)

\begin{tabular}{|c|c|c|c|c|c|c|}
\hline Buleji & & Air temperature & Salinity & Oxygen & $\mathrm{pH}$ & Chlorophyll- $a$ \\
\hline \multirow[t]{3}{*}{ Seawater temperature } & Pearson Correlation & $0.832 * *$ & -0.387 & -0.347 & -0.184 & -0.266 \\
\hline & Sig. (2-tailed) & 0.000 & 0.112 & 0.158 & 0.465 & 0.366 \\
\hline & $\mathrm{N}$ & 18 & 18 & 18 & 18 & 18 \\
\hline \multirow[t]{3}{*}{ Oxygen } & Pearson Correlation & -0.343 & $0.662 * *$ & 1 & $0.626 * *$ & $0.781 * *$ \\
\hline & Sig. (2-tailed) & 0.163 & 0.003 & & 0.005 & 0.000 \\
\hline & $\mathrm{N}$ & 18 & 18 & 18 & 18 & 18 \\
\hline \multirow[t]{3}{*}{$\mathrm{pH}$} & Pearson Correlation & -0.081 & $0.925^{* *}$ & $0.626^{* *}$ & 1 & $0.667 * *$ \\
\hline & Sig. (2-tailed) & 0.750 & 0.000 & 0.005 & & 0.002 \\
\hline & $\mathrm{N}$ & 18 & 18 & 18 & 18 & 18 \\
\hline \multirow[t]{3}{*}{ Chlorophyll- $a$} & Pearson Correlation & -0.300 & $-0.574^{*}$ & $0.781 * *$ & $0.667 * *$ & 1 \\
\hline & Sig. (2-tailed) & 0.226 & 0.013 & 0.000 & 0.002 & \\
\hline & $\mathrm{N}$ & 18 & 18 & 18 & 18 & 18 \\
\hline \multicolumn{7}{|l|}{ Paradise Point } \\
\hline \multirow[t]{3}{*}{ Seawater temperature } & Pearson Correlation & $0.880 * *$ & $-.633 * *$ & -.234 & -.345 & -.251 \\
\hline & Sig. (2-tailed) & 0.000 & 0.005 & .350 & .161 & .316 \\
\hline & $\mathrm{N}$ & 18 & 18 & 18 & 18 & 18 \\
\hline \multirow[t]{3}{*}{ Oxygen } & Pearson Correlation & -0.078 & 0.353 & 1 & $-0.576^{*}$ & $0.761 * *$ \\
\hline & Sig. (2-tailed) & 0.759 & 0.151 & & 0.012 & 0.000 \\
\hline & $\mathrm{N}$ & 18 & 18 & 18 & 18 & 18 \\
\hline \multirow[t]{3}{*}{$\mathrm{pH}$} & Pearson Correlation & -0.061 & $.621 * *$ & $.576^{*}$ & 1 & $.522 *$ \\
\hline & Sig. (2-tailed) & 0.811 & .006 & .012 & & .026 \\
\hline & $\mathrm{N}$ & 18 & 18 & 18 & 18 & 18 \\
\hline \multirow[t]{3}{*}{ Chlorophyll- $a$} & Pearson Correlation & -0.158 & 0.250 & $0.761 * *$ & $0.522^{*}$ & 1 \\
\hline & Sig. (2-tailed) & 0.530 & 0.317 & 0.000 & 0.026 & \\
\hline & $\mathrm{N}$ & 18 & 18 & 18 & 18 & 18 \\
\hline
\end{tabular}




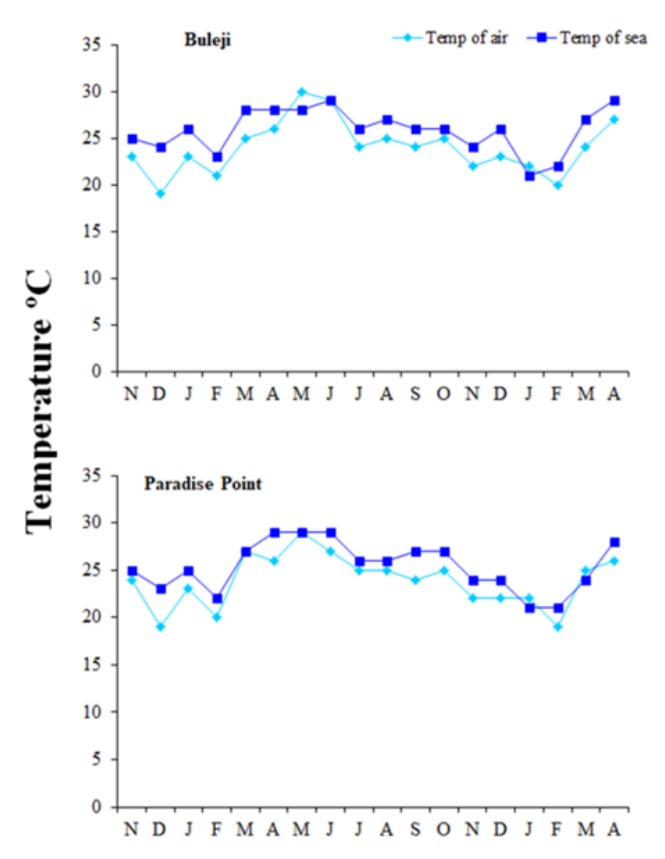

Months

Fig 2. Monthly variations in the air and surface water temperatures at Buleji and Paradise Point from November 2007 to April 2009
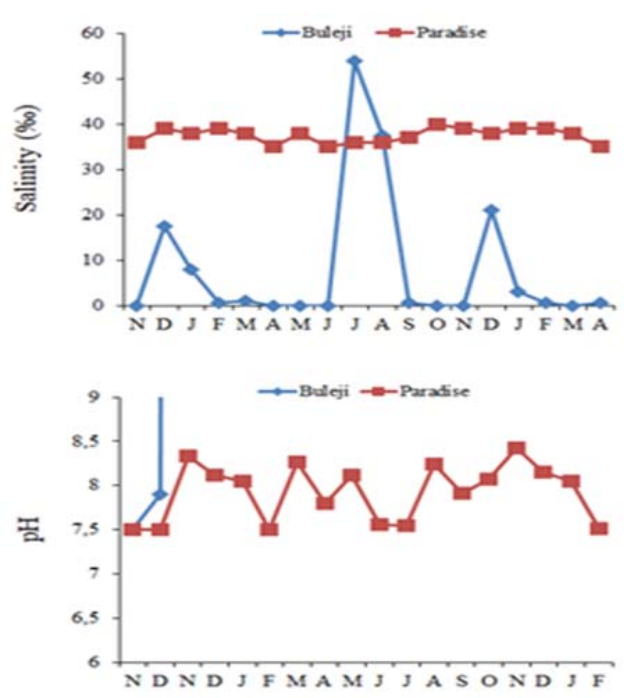

The concentration of chlorophyll- $a$ varied from 1.2 to $3.7 \mu \mathrm{g} \mathrm{cm}^{-2}$ at Buleji while it ranged between 0.9 to $3.3 \mu \mathrm{g} \mathrm{cm}^{-2}$ at Paradise Point (Figure 3).

There was a seasonal pattern in the concentration of chlorophyll- $a$ being comparatively higher in spring inter-monsoon and NE monsoon at both sites (Table 1). There was a significant correlation between $\mathrm{pH}$ and dissolved oxygen at both sites (Table 2).

The analysis of variance showed significant difference between chlorophyll-a (ANOVA, F $=4.532 ; \mathrm{P}<0.05)$ concentration at two sites, being higher (average $2.9 \pm 0.69 \mu \mathrm{g} \mathrm{cm}-2$ ) at Buleji than at Paradise Point (average $2.4 \pm$ $0.61 \mu \mathrm{g} \mathrm{cm}-2)$. The concentration of chlorophyll- $a$ was positively correlated to concentration of oxygen and $\mathrm{pH}$ (Table 2) at both sites.

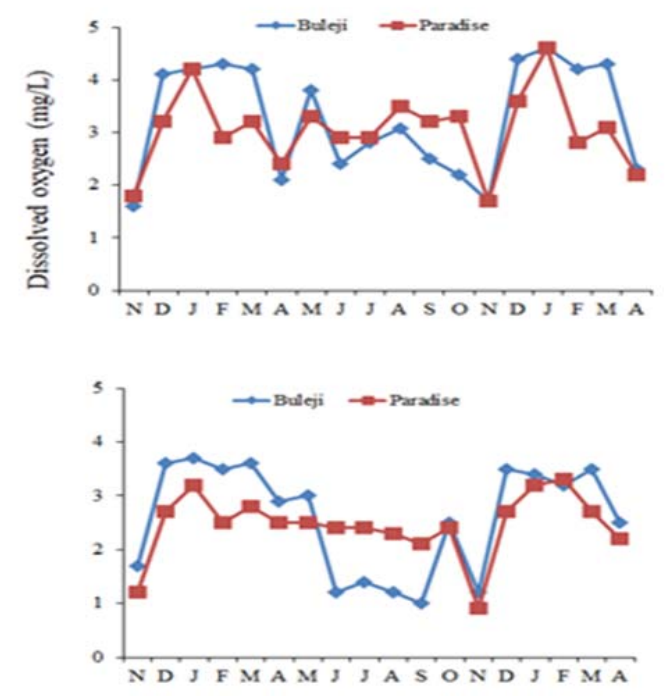

\section{Months}

Fig 3. Monthly variations in physico-chemical parameters on the rocky ledges of Buleji and Paradise Point from November 2007 to April 2009. 

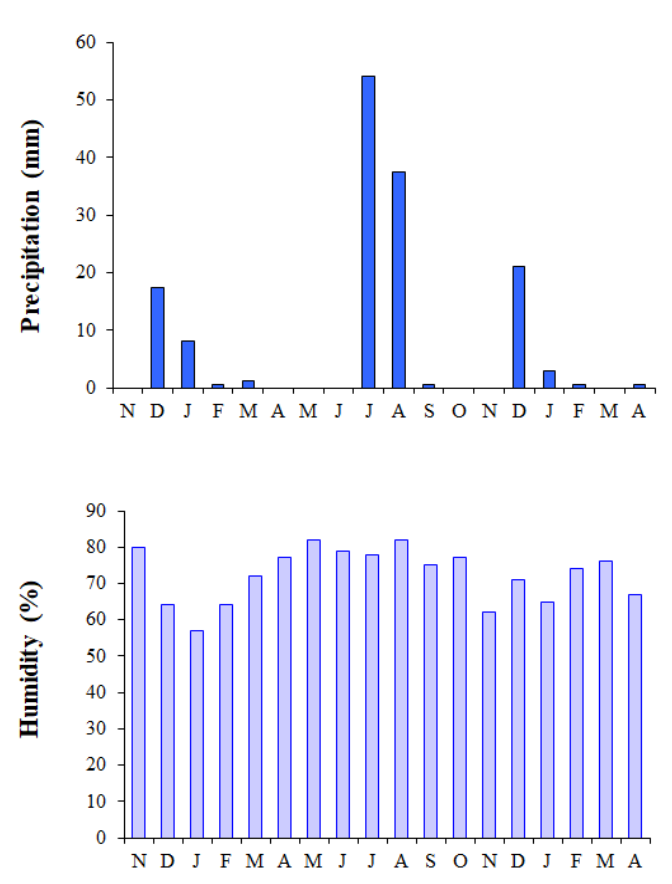

Months

Fig 4. Monthly variations in precipitation and mean humidity for Karachi from November 2007 to April 2009 (data provided by Pakistan Meteorological Department, Karachi).

\section{Discussion and Conclusion}

Life of all marine organisms depends on water quality of the coastal environment. Water quality indices are the basic tools to sketch out the environmental or ecological condition of a water body and to simplify the presentation of results. Most considerable physical and chemical factors which greatly influence the aquatic environment are temperature, $\mathrm{pH}$, salinity, carbon dioxide and dissolved oxygen. Usually the growth of aquatic organisms is not directly influenced by temperature but it can cause some indirect effects. Temperature may be the one of the reason of thermal stratification in the oceans (Elahi et al. 2015). The normal range of the temperature to which fish is adapted is between $8^{\circ} \mathrm{C}$ and $30^{\circ} \mathrm{C}$ (Alabaster and Lloyd 1980). In the present study the air temperature ranged from 19 to $30^{\circ} \mathrm{C}$ and seawater temperature ranged from 21 to $29^{\circ} \mathrm{C}$ at both the stations (see Figure 2). These ranges are desirable and optimum for the growth of marine organisms. Another fundamental physico-chemical parameter is salinity which affects biota greatly. Mostly aquatic life restrains its ionic balance and osmotic pressure to a limited range of salinity. Generally, the range of salinity of euhaline seas is from 30 to $40 \%$. In the present research trial, salinity ranged between 35 to $39 \%$ at Buleji and 35 to $40 \%$ at Paradise Point (see Figure 3). Although the salinity did not differ much throughout the year, the lowest salinity was recorded in the SW monsoon, at both sites (see Table 1). Among the key variables of water quality parameters, $\mathrm{pH}$ is the important one. Quality of water is greatly influenced by the change in $\mathrm{pH}$ and these changes are accompanied by the variations in other various physico-chemical aspects. Abowei (2010) observed that ideal $\mathrm{pH}$ for biological productivity is between 7.0 to 8.5 , while less than 4.0 is harmful for marine organisms Optimal range of $\mathrm{pH}$ for fish recommended by (EPA, 2002 and 2014) is from 6.5 to 8.5.

In the present study the $\mathrm{pH}$ value ranged from 7.0 to 8.3 at Buleji and from 7.5 to 8.4 at Paradise Point (Figure 3). Though no seasonal pattern was evident in the $\mathrm{pH}$ values at two sites, however, it was comparatively higher in autumn inter-monsoon and NE monsoon (Table 1). The values of $\mathrm{pH}$ from both locations were found to be under permissible limit $(\mathrm{pH}$ 6.58.5) for the growth of aquatic life.

The most important factor for the development, physiological activities and continued existence of aquatic life is the amounts DO in water (Solis 1988). Several scientific studies suggest that DO between the range of $4-9 \mathrm{mg} / \mathrm{L}$ is most favorable to support a large, diverse fish population (Abdus-Salam et al. 2010). Depending on the species, minimum requirements of dissolved oxygen may range from $4 \mathrm{mg} / \mathrm{L}$ to $1 \mathrm{mg} / \mathrm{L}$ (Solis 1988). Striped bass, American shad and white perch thrive in levels more than $5 \mathrm{mg} / \mathrm{L}$. (Ramanathan, et al. 2005). Billfish is not found in waters with less than $3.5 \mathrm{mg} / \mathrm{L}$ of DO, while marlins and sailfish require minimum DO of $1.5 \mathrm{mg} / \mathrm{L}$ (Courtney and Brodziak 2010). Significant ecological parameters for tuna are the sea surface 
temperature, the quantity of dissolved oxygen in the water and the salinity. Lower thermal limits vary between $10^{\circ} \mathrm{C}$ for temperate tunas and $18^{\circ} \mathrm{C}$ for tropical tunas. The minimum oxygen necessity is estimated between 2 to 2.7 $\mathrm{ml} / \mathrm{l}$ for principal market tuna species except for bigeye tuna which can tolerate oxygen concentrations as low as $0.6 \mathrm{ml} / 1$ (FAO 2000).Fishes start to leave areas where DO is less than $3.7 \mathrm{mg} / \mathrm{L}$ (EPA 2000). Invertebrates organism also disappear at the level lower than $2.0 \mathrm{mg} / \mathrm{L}$, and less than $1 \mathrm{mg} / \mathrm{L}$ value of $\mathrm{DO}$ reduced growth of benthos (EPA 2000). Mussels, oysters and clams require a minimum of 1-2 $\mathrm{mg} / \mathrm{L}$ of dissolved oxygen despite being bottom dwellers (EPA 2000). In the present study the lowest concentrations of dissolved oxygen $1.6 \mathrm{mg} \mathrm{L}^{-1}$ and $1.7 \mathrm{mg} \mathrm{L}^{-1}$ were recorded in November'07 and November'08, respectively at Buleji and Paradise Point (see Figure 3). There was a seasonal pattern in the concentration of dissolved oxygen at Buleji, being highest $\left(3.7 \pm 1.36\right.$ and $\left.3.6 \pm 1.30 \mathrm{mg} \mathrm{L}^{-1}\right)$ in NE monsoon and lowest $\left(2.2 \pm 0.00 \mathrm{mg} \mathrm{L}^{-1}\right)$ in autumn inter-monsoon. However, this seasonal pattern of dissolved oxygen concentration was not so evident at Paradise Point (Table 1). The solubility of oxygen declines as temperature and salinity increase. DO criteria may be used appropriately in a risk assessment framework (EPA 2000). Extended periods of minimal DO directly affect larval stages of various aquatic organisms adversely (EPA 2002). According to EPA that if DO is more than $4.8 \mathrm{mg} / \mathrm{L}$, the site fulfills objectives for protection, but if it is less than $2.3 \mathrm{mg} / \mathrm{L}$, the location does not fulfill objectives for protection. On the other hand, the values $r$ in between these, suggests that the location requires assessment to measure intensity of hypoxia and aquatic life safety measures (EPA 2000). The concentration of chlorophyll-a varied from 1.2 to $3.7 \mu \mathrm{g} \mathrm{cm}^{-2}$ at Buleji, while it ranged between 0.9 to $3.3 \mu \mathrm{g} \mathrm{cm}^{-2}$ at Paradise Point (Figure 3).

Seasonal pattern in the concentration of chlorophyll-a was observed being comparatively higher in spring inter-monsoon and NE monsoon at both sites (Table 1), same as Dey and Singh (2003a) observed the higher chlorophyll concentration during the northeast monsoon compared to those during the pre- and post-monsoon period and also in the coastal water compared to the open ocean. They also observed higher chlorophyll concentration in the northern Arabian Sea is attributed with the winter cooling phenomena during the months of January to March. Vice versa the results of Jamshidi and Bin Abu Bakar (2011) found the greater concentrations of chlorophyll- $a$ in midsummer than other seasons due to layers on the sea surface receive sufficient amount of sunlight in summer. Moreover besides the extent of light, nutrient concentrations and assimilation of the adjacent coastline also influence on chlorophyll- $a$. At both study sites chlorophyll- $a$ concentrations altered with the aspects that affect phytoplankton growth. Due to the presence of chlorophyll content (Chauhan et al. 2001) observed that the northeastern part of the Arabian Sea is one of the high productive zones.

Conclusively, presented data in this manuscript provide a preliminary knowledge on the physicochemical properties content at two rocky shores; Buleiji and Paradise Point located at Karachi coast. The obtained values of temperatures, salinity, $\mathrm{pH}$ and chlorophyll- $a$ are favorable for the continued existence of biota and they are within the recommended values of the World Health Organization (WHO) and Environmental Protection Agency (EPA). The values of dissolved oxygen were found to be below $4 \mathrm{mg} / \mathrm{L}$ which are not suitable for various species. Extended periods of minimal DO directly affect larval stages of various aquatic organisms adversely. In Karachi, seasonal accessibility of surface water is vastly reactive to the monsoon climate and physiography of coastal belt.

\section{Conflict of interest statement}

We declare that we have no conflict of interest..

\section{Acknowledgements}

A part of the data used in the present study has formerly been the subject of a doctoral thesis of Fatima Hayat Shaheen Zafar prepared in University of Karachi 


\section{References}

Abdus-Salam, N., Adekola, F.A., Apata, A. O. 2010. A physicochemical assessment of water quality of oil producing areas of Ilaje, Nigeria. Advances in Natural and Applied Sciences, 4: (3) 333-345.

Abowei, J.F.N. 2010. Salinity, Dissolved Oxygen, $\mathrm{pH}$ and Surface Water Temperature Conditions in Nkoro River, Niger Delta, Nigeria. Advance Journal of Food Science and Technology 2: (1) 36-40,

Alabaster, J.S. and Lloyd, R. 1980. Water Quality Criteria for Freshwater Fish. International review of Hydrobiology. 66: (3) p. 297.

Alabaster, J.S., Lloyd, R., 1980. Water quality criteria for fresh water fish 2 nd edition, $\mathrm{p}$. 325.

Anitha, G., Sugirtha, P. Kumar. 2013. Seasonal variations in Physico-Chemical parameters of the Ngapattanam estuary, South west coastal zone, Tamilnadu, India. International journal of environmental sciences. 3:(4) 1253-1261

APHA. 2005. Standard methods for examination of water and wastewater. $21 \mathrm{st}$ Edition., Washington D.C.

Badran, I. 2001. Dissolved oxygen, chlorophyll a and nutrients: seasonal cycles in waters of the Gulf Aqaba, Red Sea. Journal of Aquatic Ecosystem Health \& Management. 4: (2) 139-150.

Bat, L., Gökkurt Baki O. 2014. Seasonal variations of sediment and water quality correlated to land-based pollution sources in the middle of the Black Sea coast, Turkey. International Journal of Marine Science, 4 (12): 108-118. doi: 10.5376/ijms.2014.04.0012.

Boyd, C.E. 1979. Water quality in warm water fish ponds. Alabama: University Press;, p. 59.

Boyd, C.E., Lichtkoppler, F.R. 1979. Water quality management in pond fish culture. Research and Development Series. 22, 30.

Brill, R. 1994. A review of temperature and oxygen tolerance studies of tunas pertinent to fisheries oceanography, movements models and stock assessments. Fisheries Oceanography. 3 (3): 204-216.

Chauhan, P., Nagur, C. R. C., Mohan, M., Nayak, S. R., Navalgund, R. R. 2001.
Surface chlorophyll distribution in Arabian Sea and Bay of Bengal using IRS-P4 ocean color monitor satellite data. Current Science. 80: 127 - 129 .

Courtney, D., Brodziak, J. 2010. Oceanographic Features in the Vicinity of a North Pacific Sword fish Stock Boundary. Honolulu, HI: NOAA Fisheries, Pacific Islands Fisheries Science Center. Retrieved from:

http://isc.ac.affrc.go.jp/pdf/BILL/ISC10_BI LL_1/BILL_Apr10_FINAL_WP04.pdf.

Dey, S., Singh, R.P. 2003a. Comparison of chlorophyll distributions in the northeastern Arabian Sea and southern Bay of Bengal using IRSP4 Ocean Color Monitor data. Remote Sensing of Environment 85: 424428.

Elahi, N., Ahmed,Q., Bat, L., Yousuf, F. 2015. Physicochemical parameters and seasonal variation of coastal water from Balochistan coast, Pakistan. Journal of Coastal Life Medicine. 3(3): 199-203.

EPA. 2002 National Recommended Water Quality Criteria. EPA-822-R-02-047, pp. 36.

EPA. 1986. Quality Criteria for Water. Washington DC: Office of Water Regulations and Standards.

EPA. 2000. Ambient Aquatic Life Water Quality Criteria for Dissolved Oxygen (Saltwater): Cape Cod to Cape Hatteras. Washington DC: Office of Water : Office of Science and Technology. Retrieved from http:// water. epa. gov/ scitech/ swguidance/ standards/ upload/ 2007_03_01_criteria_dissolved_docriteria. pdf.

EPA. 2002. National recommended water quality criteria :). Washington D.C. Fisheries and Aquaculture Department. (2000). Biological characteristics of tuna. In FAO Fisheries and Aquaculture Department.Retrievedfromhttp://www.fao.o $\mathrm{rg} /$ fishery/topic/16082/en

EPA. 2002. National recommended water quality criteria: Washington D.C.: EPA; 2002. [Online] Available from: http://water.epa.gov/scitech/ swguidance / standards / upload/ 2008_04_29_criteria_wqctable_nrwqc2002.pdf [Accessed on 27th September, 2014]. 
Fisheries and Aquaculture Department. 2000. Biological characteristics of tuna. In FAO Fisheries and Aquaculture Department. Retrieved from http://www.fao.org/fishery/topic/16082/en.

Gökkurt Baki, O. 2011. Coastal management in Sinop Province (Doctoral dissertation, dissertation]. Samsun: Ondokuz Mayis University, Institute of Science).

Gökkurt, O. 2007. The effects of potential sewage points to the water quality and the organisms on the coast of Sinop. [dissertation]. Samsun: Ondokuz Mayis University, Institute of Science; Turkish.

HMSO.1986. The determination of chlorophyll$a$ in aquatic environments. In: Methods for the examination of water and associated materials.4 :(2)6-13.

Jamshidi, S., Bin Abu Bakar, N. 2011. A study on distribution of chlorophyll-a in the coastal waters of Anzali Port, south Caspian Sea. Ocean Science Discussion. 8: 435-451.

Largler, K.F., Badach, J.E., Miller, R.R., Passimo, D.R.M. 1977. Ichthyology. New York: John Wiley and Sons Inc. p. 506.

Lawson, E.O. 2011. Physico-Chemical Parameters and Heavy Metal Contents of Water from the Mangrove Swamps of Lagos Lagoon, Lagos, Nigeria. Advances in Biological Research 5 (1): 08-21.

Manasrah, R., Raheed, M., Badran, M.I. 2006. Relationships between water temperature, nutrients and dissolved oxygen in the northern Gulf of Aqaba, Red Sea. Oceanologia. 48 (2): 237-253.

Manjare, S.A., Vhanalakar, S.A., Muley, D.V. 2010. Analysis of water quality using physico-chemical parameters of Tamdalge tank in Kolhapur district, Maharashtra. International Journal of Advanced Biotechnology and Research 1: (2) 115-119.

Moazzam, M., Ahmed, J. 1994. Prospects of development of molluscan fisheries in Pakistan. In: Proceedings of national seminar on fisheries policy and planning (Eds. Majid, A., Khan, M. Y., Moazzam, M. and Ahmed, J.). Marine Fisheries Department, Govt. of Pakistan. p. 41-76.

Muduli, B., Prasanna, P. C. R. 2010. Physico chemical properties of water collected from Dhamra estuary, International journal of environmental sciences 1:(3) 334-342.
Odum, E.P. 1971. Fundamentals of ecology. Philadelphia: W.B. Saunders Co: p. 574.

Priyanka, T., Amita, B., Sukarma, T. 2009. Evaluation of water quality: Physicochemical characteristics of Ganga River at Kanpur by using correlation study. Nature and Science 1 :(6) 91-94.

Ramanathan, N., Padmavathy, P., Francis, T., Athithian, S., Selvaranjitham, N. 2005. Manual on polyculture of tiger shrimp and carps in freshwater. Thothukudi: Tamil Nadu Veterinary and Animal Sciences University, Fisheries College and Research Institute; p. 1-161.

Rizvi, S. H. N., Khan, T. M. A., Ali, S. M., Baquer, J. 1995. Circulation patterns in the Karachi coastal waters in relation to the outfalls. In: The Arabian Sea, Living Marine Resources and the Environment (Eds. Thompson M. F. and Tirmizi N. M.). Vanguard Books (Pvt) Ltd., Lahore, Pakistan. Pp. 641-652.

Sadorus, L. L. 2012. The influence of environmental factors on halibut distribution as observed on the IPHC stock assessment survey: A preliminary examination.

Saifullah, S. M. 1973. A preliminary survey of the standing crop of sea weeds from the Karachi coast. Botanica Marina. 16: 139144.

Solis, N.B. 1988. Biology and ecology of Penaeus monodon. In: Biology and culture of Penaeus monodon. Iloilo: SEAFDEC Aquaculture Department; p. 3-36.

Soundarapandian, P., Premkumar, T., Dinakaran, G.K. 2009. Studies on the physico-chemical characteristic and nutrients in the Uppanar estuary of Cuddalore, South east coast of India. Current Research Journal of Biological Science, 1: (3) 102-105.

Sreenivasulu, G., Jayaraju, G. N., Sundara Raja Reddy, B.C., Lakshmi Prasad, T. 2015. Physico-chemical parameters of coastal water from Tupilipalem coast, Southeast coast of India. Journal of Coastal Sciences 2: 34-39

Sreenivasulu, G., Jayaraju1, N.,. Sundara Raja Reddy, B.C., Lakshmi Prasad,T. 2015. Physico-chemical parameters of coastal water from Tupilipalem coast, Southeast 
coast of India. Journal of Coastal Sciences. 2: (2) 34-39.

Suski, C.D., Killen, S.S., Keiffer, J.D., Tufts, B.L. 2006. The influence of environmental temperature and oxygen concentration on the recovery of largemouth bass from exercise: implications for live-release angling tournaments. Journal of Fish Biology; 68: 120-136.

Tariq, M. A. K., Razzaq, D. A., Chaudhry, Q, Z. Quadir, D. A., Kabir, A and Sarker, M. A. 2002. Sea level variations and geomorphological changes in the coastal belt of Pakistan. Marine Geodesy. 25:159 174.

Thakur, B., Chavda, C., Salvi, H. 2014. Winter Season Variations In Physicochemical
Parameters Of Marine Water Characteristics Of Coral Reef Of the Poshitra Coast, Paga Reef And Boria Reef of Southwest Gulf of Kachchh, India. International journal of scientific \& technology research. 3: (7) 270273.

Trivedi, J.N., Gadhavi, M.K, Vachhrajani, K.D. 2012. Diversity and habitat preference of Brachuran crabs in Gulf of Kachchh, Gujarat, India. Arthropods. 1(1): 13-23.

Turkish Environmental Regulations: December 13, 2004. Water Pollution Control Regulation Law No: 2872, Official Gazette No: 25687. 
APPENDIX
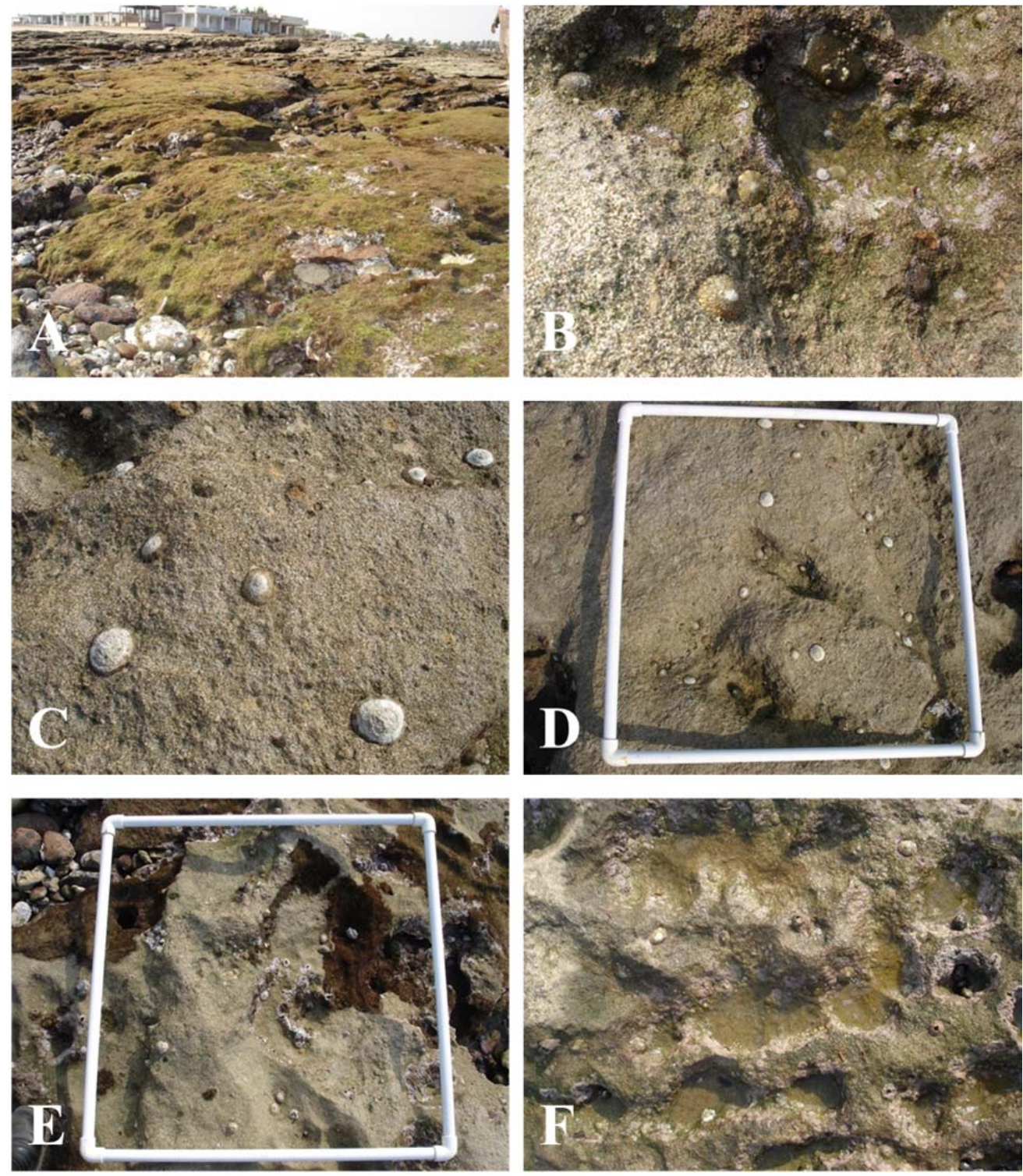

Plate 1. Photographs showing population of limpets at Buleji. A- view of Buleji rocky shore. B,C and F- colour variations in Cellana karachiensis . D and E-Placement of $50 \mathrm{~cm}$ x $50 \mathrm{~cm}$ quadrat for sampling. 

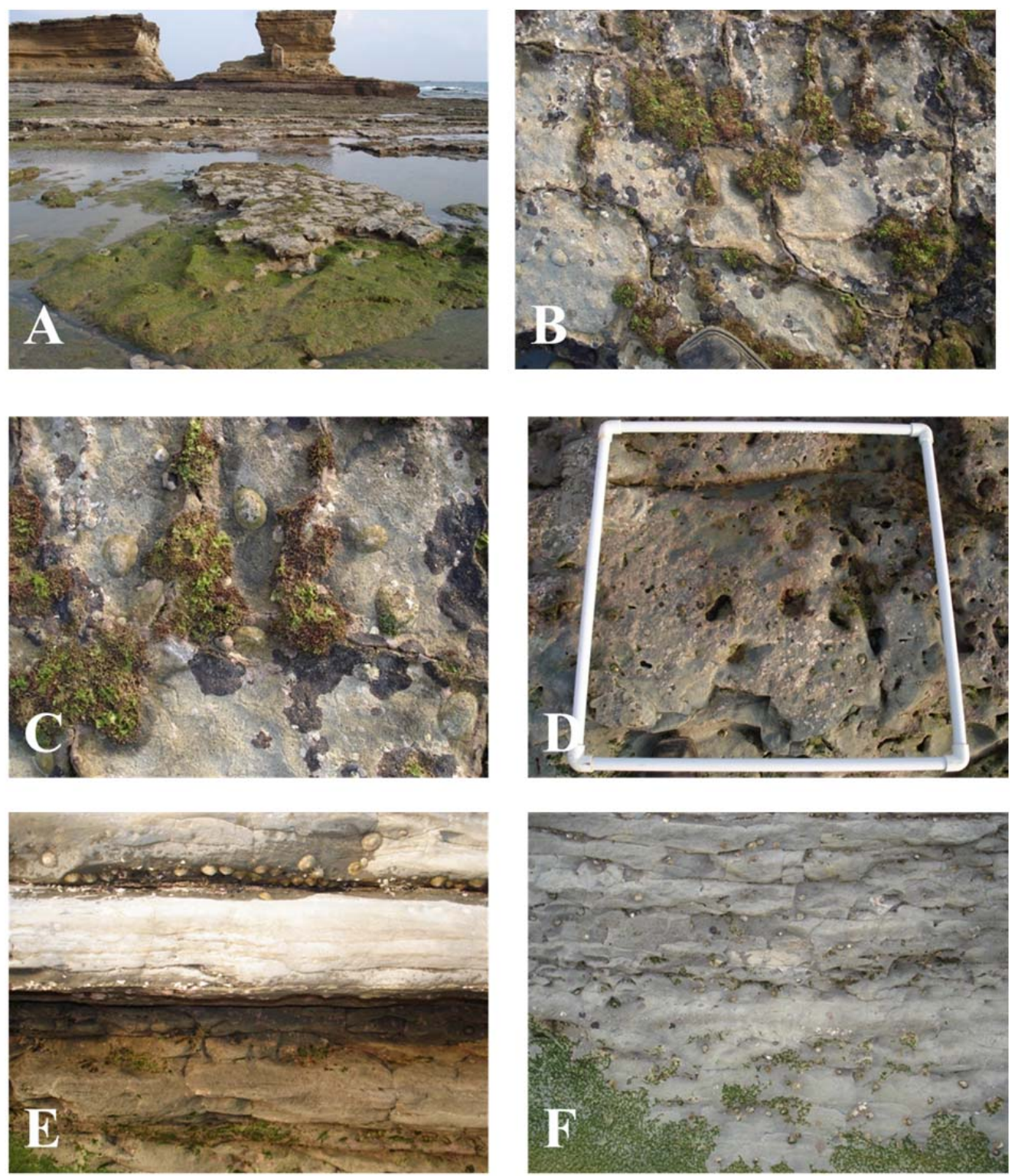

Plate 2. Photographs showing population of limpets at Paradise Point. A- view of Paradise Point rocky shore. B and C - population of Cellana karachiensis. D - Placement of $50 \mathrm{~cm} \mathrm{x} 50 \mathrm{~cm}$ quadrat for sampling. $\mathrm{E}$ and $\mathrm{F}$-population of limpets on the mountains. 